\title{
Impact Of Asset Age/Fiscal Viability On Selected Measures Of Patient Care In Nursing Homes
}

Jim Morey, (E-mail: fjhm@sunyit.edu), SUNY Institute of Technology

Hoseoup Lee, (E-mail: leeh@sunyit.edu), SUNY Institute of Technology

Ken Wallis, (E-mail: Kenneth.wallis@sunyit.edu), SUNY Institute of Technology

\begin{abstract}
Forty-five New York nursing homes were examined to determine if a relationship between age of assets, fiscal viability and quality of nursing homes, as measured by patient care indices and survey deficiencies, existed. These factors were examined on 2004 data for the nursing homes selected. Several financial variables were used to construct a fiscal viability index; and a patient care index was created from selected procedural measures that may be used to measure specific aspects of institutional care. The premise is that age of assets and fiscal viability will influence quality of patient care/survey deficiencies. Utilizing both the financial and patient care and survey indices, the following statistical models were prepared:
\end{abstract}

\section{INTRODUCTION}

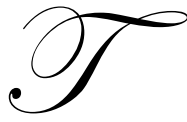

he purpose of this study of New York State nursing homes was to examine whether, if any, (1) the age of assets has an effect on a fiscal viability index, 2) the age of assets has an effect on each of the specific fiscal viability index, and (3) the impact age of assets and the fiscal viability index have on the quality of patient care/survey indices. A similar study involving New York State hospitals was undertaken in 2005 (Morey et. al., 2005)

In general terms, fiscal viability and quality indicators of institutional care are measures that would take some time to manifest; however, a one-year snapshot on those variables would enable us to examine a potential relationship. Forty-five nursing homes in New York State were chosen due to the availability of data for these nursing homes for both fiscal and patient care quality and survey deficiency indicators.

\section{METHODOLOGY}

The methodology used the age of plant, fiscal ratios and patient care data to create indexes in which we could analyze correlations.

Various fiscal ratios, as outlined by Cleverly (Cleverly, 1997), were utilized to determine age of plant and to construct the fiscal viability index. These ratios are presented on Table 1.

The financial ratios were "combined" into a fiscal viability index utilizing the calculated ratios of the sample nursing homes. Specifically, the index was constructed using the following:

- $\quad$ Fiscal viability from Profitability: for each positive ratio, a score of .5 was assigned; and

- $\quad$ Fiscal viability from Capital Structure: for each positive ratio, a score of 1.0 was assigned.

Thus, an overall fiscal viability rating for each nursing home ranged from 0 (low) to 3 (high). 
Table 1. Variables And Ratios That Determine Age Of Asset And Fiscal Viability

\begin{tabular}{|l|l|l|}
\hline \multicolumn{1}{|c|}{ Variables } & \multicolumn{1}{c|}{ Ratio } & \multicolumn{1}{c|}{ Formula } \\
\hline Age of asset & Age of asset in years & Allowance for depreciation $\div$ annual depreciation expense \\
\hline \multirow{2}{*}{ Fiscal viability from profitability } & (1) Income margin & Net income $\div$ total operating revenue \\
\cline { 2 - 3 } & (2) Return on equity & Net income $\div$ unrestricted net asset \\
\hline \multirow{2}{*}{ Fiscal viability from capital structure } & (3) Equity financing & Unrestricted net asset $\div$ total asset \\
\cline { 2 - 3 } & (4) Cash flow to debt & (Net income + depreciation) $\div$ total liabilities \\
\hline
\end{tabular}

Source: Cleverly, W.O. 1997. Essentials of Health Care Finance, Fourth Edition. Aspen Publication.

The patient care measures employed were the 15 Federal Medicare quality measures presented by the Center for Medicare and Medicaid (http://www.medicare.gov/NHcompare). The measures they presented were gleaned from national database known as the Minimum Data Set (MDS) Repository.

The MDS is collected on regular intervals for every resident in Medicare or Medicaid certified nursing homes. Information is collected on the resident's health, physical functioning, mental status, and general well-being. These data are used by the nursing home to access the needs and develop a plan of care unique to each resident.

Selected MDS items used to calculate the quality measures covers the resident's conditions during days prior to the assessment date. Table 2 provides these "observation" or "look back" time frames.

Table 2 - Medicare Quality Indicators For Nursing Home Patients

\begin{tabular}{|l|l|}
\hline \multicolumn{1}{|c|}{ Quality - Long Term Measures } & \multicolumn{1}{|c|}{$\begin{array}{c}\text { MDS Observation } \\
\text { Time Frame * }\end{array}$} \\
\hline Percent of Residents Whose Need for Help With Daily Activities Has Increased & Looks back 7 days \\
\hline Percent of Residents Who Have Moderate to Severe Pain & Looks back 7 days \\
\hline Percent of High-Risk Residents Who Have Pressure Sores & Looks back 7 days \\
\hline Percent of Low-Risk Residents Who Have Pressure Sores & Looks back 7 days \\
\hline Percent of Residents Who Were Physically Restrained & Looks back 7 days \\
\hline Percent of Residents Who are More Depressed or Anxious & Looks back 30 days \\
\hline Percent of Low-Risk Residents Who Lose Control of Their Bowels or Bladder & Looks back 14 days \\
\hline Percent of Residents Who Have/Had a Catheter Inserted and Left in Their Bladder & Looks back 14 days \\
\hline Percent of Residents Who Spent Most of Their Time in Bed or in a Chair & Looks back 7 days \\
\hline Percent of Residents Whose Ability to Move About in and Around Their Room Got Worse & Looks back 7 days \\
\hline Percent of Residents with a Urinary Tract Infection & Looks back 30 days \\
\hline Percent of Residents Who Lose Too Much Weight & Looks back 30 days \\
\hline
\end{tabular}

Source: Centers For Medicare and Medicaid Services (http://www.medicare.gov/NHcompare)

For each measure, data was presented that compared the nursing home with the State percentage rate and the National percentage rate. If the nursing home's rate was consistent with the State rate, the nursing home was considered to have a rate similar to the State's. If the nursing home rate was above or below the State rate, it was considered to be better or worse regarding the quality of nursing home.

For example, a nursing home received 2 when its rate was similar to the rate of New York State, 1 if the rate was significantly worse than the mean, and 3 if better. These scores were then used to create an index score for the nursing homes in the sample.

Another quality measure examined was the number of survey deficiencies that each nursing home incurred on its most recent inspection. Nursing homes are inspected annually under the auspices of the Center for Medicare and Medicaid. Results from these surveys are provided under the heading of "deficiencies." The severity of 
deficiency was not measured in this examination. Instead, total number of deficiencies was combined for each nursing home to glean the frequency of deficiency.

\section{FINDINGS}

\section{Data Analysis}

Table 3 provides descriptive statistics of variables used in this study including age of asset, fiscal viability index, and quality of nursing home care and survey deficiency index. Four variables constituting the fiscal viability index are quite volatile, especially for the return on net assets and equity financing percent, justifying the conversion process used in this study. An interesting implication in this nursing home sample is that the mean return on net asset measure is negative. With the negative median return on asset, a majority of nursing homes in this sample are experiencing significantly negative return on their net assets.

Table 3 presents descriptive statistics for the sample.

Table 3. Descriptive Statistics Of 45 Nursing Home Sample

\begin{tabular}{|ccccc|}
\hline Variable & N & Mean & Standard deviation & Median \\
\hline Asset age & 45 & 13.91 & 5.24 & 12.64 \\
Total fiscal viability index & 45 & 2.03 & 1.05 & 2.0 \\
Quality index & 45 & 2.27 & 0.40 & 2.27 \\
Survey deficiency index & 45 & 6.4 & 4.38 & 6.0 \\
Income margin & 45 & $1.42 \%$ & $11.9 \%$ & $-0.31 \%$ \\
Return on net asset & 45 & $-14.5 \%$ & $100.3 \%$ & $-1.4 \%$ \\
Net asset equity \% & 45 & $16.97 \%$ & $42.7 \%$ & $22.56 \%$ \\
CF over debt & 45 & $65.9 \%$ & $325 \%$ & $5.56 \%$ \\
\hline
\end{tabular}

\section{Analysis Of Results}

Model 1: Effect Of Asset Age On Fiscal Viability Index ( $N=45)$

The first research question of this study is whether age of assets might affect fiscal viability of nursing homes. When a nursing home provides rehabilitation care with state-of-art equipment and the latest technology, it may have a better chance to do better financially by providing high-margin procedures to its patients. Another rationale for the research expectation is that newly-built or renovated nursing homes may provide more efficient care for its residents and be more marketable to the purchasers of such care.

As provided in Table 4, our analysis indicates that age of assets has a negative impact on fiscal viability. In other words, as long-term assets of a nursing home get older, the nursing home may experience worse financial condition. Another implication of this result is that nursing homes with continuous and consistent investments in their equipments may have a greater chance to improve the financial prospects of nursing homes.

Table 4. Effect Of Asset Age On Fiscal Viability Index $(\mathbf{N}=45)$

\begin{tabular}{|ccc|}
\hline Variable & Coefficient & t-value \\
\hline Intercept & 2.4 & $5.36^{* * *}$ \\
Asset age & -0.026 & -0.88 \\
R-square & $1.76 \%$ & \\
F-value & 0.77 & \\
\hline
\end{tabular}

Significance level: *** (less than 1\%) 
$\underline{\text { Implication }}$

Negative coefficient of asset age indicates that as average asset of a nursing home gets older, fiscal viability of the nursing home deteriorates, but the magnitude of the effect is much less than that of our previous hospital study, and this nursing home result is not statistically significant. This is somewhat makes sense because nursing homes tend to be more labor-intensive in their operations than hospitals (i.e. older nursing home building does not necessarily mean a less financial efficiency). Goodness of fit measure (R-square) indicates that under this model, average asset age explains about $2 \%$ of fiscal viability. With elimination of some potential outliers in the sample, we find the negative effect of asset age intensify \& statistically significant at less than $10 \%$ level.

Model 2: Effect Of Asset Age On Individual Fiscal Viability Measures ( $N=45)$

This part of the study examined the effect of asset age on four fiscal viability measures used for this analysis, including: income margin, return on equity, equity financing, and cash flow to debt ratios.

As indicated in Table 5, age of asset in nursing home negatively affects profit margin and return on equity (Panel A \& B). In other words, as nursing homes get older, their profitability suffers. This negative effect is as expected, but not statistically significant. Panel C \& D of Table 5 show that age of asset in nursing homes affect equity financing \% positively, but cash flow to debt negatively. The effect is not statistically significant.

Table 5. Effect Of Asset Age On Individual Fiscal Viability Measures (N=45) (Panel A) Effect On Income Margin

\begin{tabular}{|ccc|}
\hline Variable & Coefficient & t-value \\
\hline Intercept & 0.03 & 0.61 \\
Asset age & -0.001 & -0.35 \\
\hline R-square & $0.29 \%$ & \\
F-value & 0.12 & \\
\hline
\end{tabular}

(Panel B) Effect On Return On Net Asset (ROE)

\begin{tabular}{|ccc|}
\hline Variable & Coefficient & t-value \\
\hline Intercept & 0.39 & 0.93 \\
Asset age & -0.04 & -1.36 \\
\hline R-square & $4.13 \%$ & \\
F-value & 1.85 & \\
\hline
\end{tabular}

(Panel C) Effect On Equity As \% Of Total Asset

\begin{tabular}{|ccc|}
\hline Variable & Coefficient & t-value \\
\hline Intercept & -0.01 & -0.03 \\
Asset age & 0.012 & 1.03 \\
\hline R-square & $2.41 \%$ & \\
F-value & 1.06 & \\
\hline
\end{tabular}

(Panel D) Effect On Operating CF As \% Of Debt

\begin{tabular}{|ccc|}
\hline Variable & Coefficient & t-value \\
\hline Intercept & 1.7 & 1.22 \\
Asset age & -0.075 & -0.8 \\
\hline R-square & $1.47 \%$ & \\
F-value & 0.64 & \\
\hline
\end{tabular}


Model 3: Effect Of Asset Age And Fiscal Viability Index On Quality Index ( $N=45)$

The ultimate research question of this study is to examine whether the quality of nursing home care, as measured by the patient care index and survey deficiency index, is affected by the age of long-term assets and its fiscal viability.

Panel A of Table 6 indicates that nursing homes with older assets and under sound financial condition have a greater chance to provide an acceptable quality of care, as reflected by the quality of care index, but both variables are not statistically significant. Panel B of Table 6 shows that nursing homes with older assets \& better financial condition get less deficiency ratings in resident survey. Effect of financial viability is significant at less than $10 \%$ level.

It is quite interesting to compare the differing effect of fiscal viability on two quality measures. As we expected, the effect of fiscal viability on resident condition quality is positive (not statistically significant, though), but that the survey deficiency index is significantly negative. This means that (1) financially strong nursing homes tend to respond to residents' need more promptly \& effectively; (2) financially strong nursing homes tend to provide less deficient care to their residents. The deficiency quality measure provides very strong implication with our results.

Table 6. Effect Of Asset Age \& Fiscal Viability Index On Quality Index (N=45) (Panel A: Patient Care Index)

\begin{tabular}{|ccc|}
\hline Variable & Coefficient & t-value \\
\hline Intercept & 2.03 & $9.08^{* * *}$ \\
Asset age & 0.011 & 0.9 \\
Fiscal viability index & 0.043 & 0.73 \\
\hline R-square & $2.75 \%$ & \\
F-value & 0.59 & \\
\hline
\end{tabular}

Significance level: *** (less than 1\%)

(Panel B: Survey deficiency index)

\begin{tabular}{|ccc|}
\hline Variable & Coefficient & t-value \\
\hline Intercept & 10.3 & $4.34^{* * *}$ \\
Asset age & -0.13 & -1.02 \\
Fiscal viability index & -1.05 & $-1.7^{*}$ \\
\hline R-square & $7.6 \%$ & \\
F-value & 1.73 & \\
\hline
\end{tabular}

Significance level: *** (less than 1\%); * (less than 10\%)

Implication

The second measure (Survey deficiency index) is much better than the first one (patience care indicator). Age of asset and fiscal viability explain much better about the quality deficiency survey than quality for resident conditions (7.6\% and $2.75 \%)$. As we expected, better fiscal conditions of nursing home improve the quality of resident care (Panel A) and decrease the nursing home deficiency (Panel B). Especially, the effect of fiscal viability on survey deficiency index is statistically significant at $10 \%$ level. However, the result also indicates nursing homes with older assets generate a better quality index (Panel A) and deficiency index (Panel B); but the effects are not significant.

This research will need further refinement of the research variables, including: various classes of long-term assets. Also, additional refinement with respect to nursing home quality and survey measures that are dependent on other resource inputs is needed. 


\section{CONCLUSION}

From this study, one can conclude the following:

1. As the age of nursing assets increases, fiscal viability of nursing home declines;

2. Nursing homes with strong fiscal viability demonstrate strong quality indicators;

3. As the age of nursing home assets increases, quality of nursing homes improves.

4. Nursing homes with weak fiscal viability demonstrate significant survey deficiencies.

Based on these conclusions, while numbers one, two and four were expected, number three is an unexpected outcome. This study was a one year "snapshot" of data; additional years, preferably two to three years, is necessary to refine the findings, and to determine if the above conclusions withstand the test of multi-year data. Also, refining age of assets to the level of a nursing home's technology expertise and human expertise will assist in further explaining number three.

\section{REFERENCES}

1. Cleverly, W.O. 1997. Essentials of Health Care Finance, Fourth Edition. Aspen Publication.

2. Centers for Medicaid and Medicare, 2006; http://www.medicare.gov/NHcompare.

3. $\quad$ IRS Form 990 for year 2002; www.Guidestar.org.

4. Impact of Asset Age/Fiscal Viability on Selected Measures of Quality In Hospitals; Journal of Business and Economics Research, November, 2005. Morey, James; Scherzer, Gary; and Lee, Hoseoup. 